\title{
Propagation of 'Bruno' kiwifruit: influence of cutting collection time and indolebutyric acid
}

\section{Propagação de kiwizeiro 'Bruno': influência da época de coleta das estacas e ácido indolbutírico}

\author{
Leonardo Zucuni Guasso ${ }^{1 *}$; Francisco Antonello Marodin²; Taís Altmann; \\ Samar Velho da Silveira3; Paulo Vitor Dutra de Souza ${ }^{4}$
}

\section{Highlights}

Rooting in kiwifruit cuttings is influenced by the collection period.

Rooting in kiwifruit cuttings is influenced by the use of IBA.

The season of largest reserve content in parent plants is also that of greatest rooting in cuttings.

\begin{abstract}
In Brazil, the propagation of kiwifruit (Actinidia deliciosa) is achieved through seed-derived rootstocks, which results in low uniformity. An alternative to address this problem is the cuttings technique, a simple and fast method that generates individuals identical to the parent plant, maintaining the agronomic traits. This study was conducted to evaluate the effects of cutting collection time and indolebutyric acid (IBA) on the rooting of 'Bruno' kiwifruit cuttings. The cuttings were collected in the months of May, August and December 2016 and March 2017 and treated with 0, 1000, 2000 and $4000 \mathrm{mg} \mathrm{L}^{-1}$ IBA, as a hydroalcoholic solution, for seven seconds. After 90 days, the percentages of rooted and dead cuttings and cuttings that produced shoots; leaf retention; average length of the three largest roots; average number of primary roots per cutting; and reserve contents before and after rooting were evaluated. The treatments with IBA influenced the rooting of cuttings collected in May, which showed $36.07 \%$ rooting at the calculated IBA concentration of 2,320 mg $\mathrm{L}^{-1}$, and in December, which exhibited $57.59 \%$ rooting at the concentration of $4000 \mathrm{mg} \mathrm{L}^{-1}$. In the present experimental conditions, it is recommended to root cuttings of 'Bruno' kiwifruit collected in December with the application of $4000 \mathrm{mg} \mathrm{L}^{-1}$ IBA.
\end{abstract}

Key words: Actinidia deliciosa. Carbohydrates. Cuttings. IBA. Kiwifruit. Plant physiology.

1 Agronomists, Students of the Doctoral Course at Postgraduate Program in Plant Science, Universidade Federal do Rio Grande do Sul, UFRGS, Porto Alegre, RS, Brazil. E-mail: leonardo.guasso@ufrgs.br; tais.altmann@ufrgs.br

2 Agronomist, M.e in Plant Science, Department of Water Resources, Secretaria do Meio Ambiente e Infraestrutura do Rio Grande do Sul, SEMA, Porto Alegre, RS, Brazil. E-mail: famarodin@hotmail.com

3 Researcher, Empresa Brasileira de Pesquisa Agropecuária, EMBRAPA Uva e Vinho, Bento Gonçalves, RS Brazil. E-mail: samar.velho@embrapa.br

4 Prof. Dr., Department of Horticulture and Silviculture, UFRGS, Porto Alegre, RS, Brazil. E-mail: pvdsouza@ufrgs.br

* Author for correspondence

Received: Oct. 29, 2020 - Approved: Feb. 05, 2021 


\section{Resumo}

No Brasil, para a propagação de kiwizeiros (Actinidia deliciosa) são utilizados porta-enxertos oriundos de sementes, resultando em baixa uniformidade. Uma alternativa é a estaquia, por ser método simples, rápido, que gera indivíduos idênticos à planta matriz, mantendo as características agronômicas. O objetivo deste estudo foi avaliar a época de coleta das estacas e o efeito do ácido indolbutírico (AIB) sobre o enraizamento de estacas de kiwizeiro 'Bruno'. As estacas foram coletadas nos meses de maio, agosto e dezembro de 2016 e março de 2017; e tratadas com zero, 1.000, 2.000 e $4.000 \mathrm{mg} \mathrm{L}^{-1}$ de AlB, na forma de solução hidroalcoólica, por sete segundos. Após 90 dias, avaliou-se a percentagem de estacas enraizadas; mortas; brotadas; retenção foliar; comprimento médio das três maiores raízes; número médio de raízes primárias por estaca, além do conteúdo de reservas antes e após o enraizamento. Os tratamentos com AlB influenciam o enraizamento das estacas coletadas em maio, com 36,07\% de enraizamento na concentração calculada de $2.320 \mathrm{mg} \mathrm{L}^{-1}$, e em dezembro, atingindo $57,59 \%$ de enraizamento na concentração de $4.000 \mathrm{mg} \mathrm{L}^{-1}$ de AIB. Nas condições do presente experimento recomenda-se o enraizamento de estacas de kiwizeiro 'Bruno' coletadas em dezembro, aplicando-se $4.000 \mathrm{mg} \mathrm{L}^{-1}$ de AIB.

Palavras-chave: Actinidia deliciosa. AIB. Carboidratos. Estaquia. Fisiologia vegetal. Kiwi.

\section{Introduction}

Kiwifruit (Actinidia deliciosa [A. Chev] C. F. Liang \& A. R. Ferguson) is a temperate climate fruit originating in the mountainous and humid areas of the Yangtze River Valley, southeastern China (Huang, 2016). This country, alongside Italy, New Zealand and Chile, accounts for over $80 \%$ of the world kiwifruit production (Food and Agriculture Organization [FAOSTAT], 2020).

In Brazil, production is concentrated in the southern region states, where soil-climatic conditions are favorable for its cultivation with cultivar Bruno being the most planted. However, national production is not enough to supply the domestic market. In 2019 alone, 30,108 t of kiwifruit were imported, representing an expense of 43.5 million U.S. dollars (Estatísticas do Comércio Exterior do Agronegócio Brasileiro [AGROSTAT], 2020). This situation tends to be accentuated in the coming years, as the emergence of the kiwifruit wilt (Ceratocystis fimbriata Ellis \& Halsted) has caused a significant reduction in its planted area (Piveta, Alfenas, Muniz, ValdebenitoSanhueza, \& Ferreira, 2013). To control this disease, actions are being developed to improve the production system, such as the selection of vegetative material resistant to wilt and the production of pathogen-free seedlings.

In a study by Pimenta (2018), resistance to $C$. fimbriata was evaluated in seed-derived seedlings, and resistant 'Bruno' half-sib plants were identified. This finding warrants improving the kiwifruit propagation methods to allow the use of these materials as rootstock in already contaminated areas, or the direct rooting of the scion variety in case this genotype has production and fruit-quality traits of interest.

Kiwifruit is usually multiplied by grafting, with rootstocks derived from seeds. Because they are functionally dioecious plants, the progeny results in individuals different from the parent plant and lack of 
uniformity. In addition, seedling formation takes a long time, requiring at least two years (Silveira et al., 2012). Propagation by cuttings allows the multiplication of progeny identical to the parent plant, with the maintenance of the agronomic traits of interest as well as greater homogeneity and faster seedling production (Xavier, Wendling, \& Silva, 2013).

In this propagation method, several factors interact for root emergence to occur. In this respect, determining the best time for collecting the cuttings is of paramount importance, as the morphophysiological condition, hormonal balance and carbohydrate content of the parent plant are altered by seasonal variations. Periods of intense vegetative growth, when temperatures are higher, are characterized by a greater amount of endogenous auxins in plants, such as indoleacetic acid (IAA), a compound synthesized in growth regions such as apices, buds and young leaves. Rooting can be stimulated in several plant species through the exogenous application of auxins, mainly indolebutyric acid (IBA), which is the most used due to its stability and effectiveness in the initiation of root primordia. However, the response to the application of auxins varies widely between species and cultivars, with the optimal concentration being specific for each genotype (Hartmann, Kester, Davies, \& Genive, 2017).

Another determining factor for the successful rooting of cuttings is the amount of carbohydrates in the parent plant (Smith \& Holzapfel, 2009). According to Bates, Dunst and Joy (2002), at the beginning of vegetative growth, most of the carbohydrates accumulated by plants in the post-harvest period of the previous cycle are transported to the leaves and branches in development, and during fruiting, these compounds are mobilized to the fruits. Thus, the period of collecting cuttings from the parent plants should be investigated to determine whether the reserve content present in the branches results in changes in the rooting of the cuttings.

In this scenario, the present study proposes to examine the influence of cutting collection time and indolebutyric acid (IBA) on the rooting of 'Bruno' kiwifruit cuttings.

\section{Material and Methods}

The study was conducted in a protected environment at the Department of Horticulture and Silviculture at the Faculty of Agronomy of the Federal University of Rio Grande do Sul (UFRGS), located in Porto Alegre, RS, Brazil.

Said site is covered with transparent plastic tiles (70\% light interception) and equipped with an intermittent misting system with four-outlet mist sprinklers.

The irrigation schedule consisted of different micro-sprinkler irrigation cycles, which varied according to the time of day and time of year. In the months of November to March, from 7h00 to $19 \mathrm{hO0}$ (daytime period), irrigation occurred for $15 \mathrm{~s}$, at 4-min intervals; and from 7 h00 to $19 \mathrm{h00}$ (nighttime period), for $15 \mathrm{~s}$, at 15-min intervals. From April to October, during the daytime period, the interval between irrigations was $8 \mathrm{~min}$, and in the nighttime period, 25 min, without changing the duration of irrigation. During the period of rooting in the greenhouse, relative humidity varied between 83 and 100\%. Figure 1 illustrates the maximum, minimum and average temperatures. 


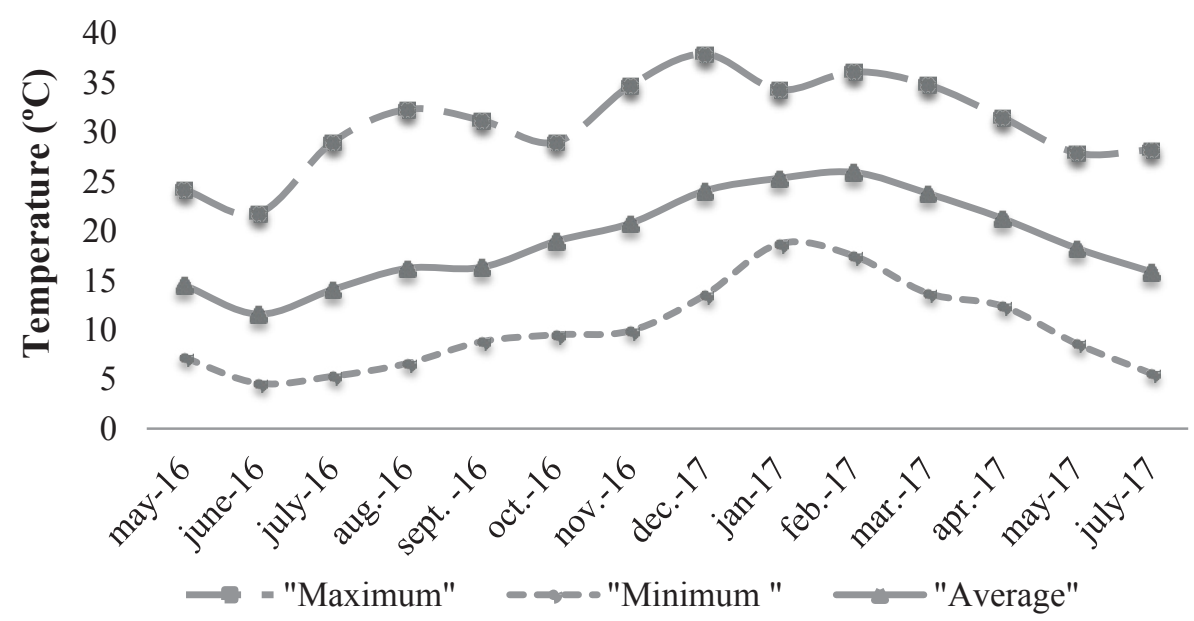

Figure 1. Maximum, minimum and average temperatures in a greenhouse with intermittent misting, between May 2016 and June 2017.

The vegetative material was obtained from branches of kiwifruit cultivar 'Bruno', originating from parent plants belonging to the orchard of the Experimental Agronomic Station at UFRGS, located in Eldorado do Sul, RS, Brazil $\left(30^{\circ} 06^{\prime} 31.33\right.$ "S and 51 $41^{\circ} 08.40^{\prime \prime}$ W). This orchard was formed in the year 2000 , trained in a ' $T$ ' support system, with a spacing of three meters between plants and five meters between rows. The parent plants received fertilization and cultural practices according to the recommendations for the kiwifruit crop (Silveira et al., 2012).

The experiment was laid out in a randomized block design with a $4 \times 4$ bifactorial arrangement whose factors were represented by the collection periods (May, August and December 2016 and March 2017) and IBA concentrations $(0,1000,2000$ and $\left.4000 \mathrm{mg} \mathrm{L}^{-1}\right)$. The experiment consisted of four blocks, each of which was composed of 12 cuttings.

During the May collection, the parent plants were at the beginning of dormancy, with the leaves in the senescence process, woody branches and without the presence of fruits. In August, branch collection was performed together with pruning, when the plants were in full dormancy, completely devoid of leaves and with woody branches. In the December collection, the plants had herbaceous branches and showed intense shooting and growth, some flowers remaining and smallcaliber fruits. Lastly, in March, the branches were semi-woody, with a high number of fruits developing and/or starting to ripen.

In the collections, which took place in the early morning, branches approximately 1-m long were removed from the parent plants. Subsequently, they were wrapped in moist newspaper, packed in plastic bags with a capacity of $100 \mathrm{~L}$ and transported immediately to the experiment site.

The cuttings were made using the middle part of the branches, each measuring 0.8 to $1 \mathrm{~cm}$ in diameter and 10 to $15 \mathrm{~cm}$ in length. Two buds were kept, one upper and one lower. A diagonal cut was made in the upper part 
of the cutting, at a distance of approximately $1 \mathrm{~cm}$ from the upper bud, whereas the basal cut was made at $0.5 \mathrm{~cm}$ from the lower bud and transverse to the cutting. Also, one leaf per cutting was maintained next to the upper bud, preserving half of its area. An exception occurred in the collection carried out in the winter, in which the parent plant had no leaves.

Indolebutyric acid was used as a concentrated hydroalcoholic solution, by dissolving indolebutyric acid $\left(\mathrm{C}_{12} \mathrm{H}_{13} \mathrm{NO}_{2}\right)$, purity greater than $98 \%\left(\mathrm{NEON}^{\circledR}\right)$, in a solvent composed of $52 \%$ ethyl alcohol $\left(96 \% \mathrm{v} \mathrm{v}^{-1}\right)$, with the rest of the volume being completed with deionized water.

After the cuttings were made, the base of each one was immersed in different IBA concentrations for seven seconds. The following concentrations were tested: 0 (deionized water), 1000, 2000 and $4000 \mathrm{mg} \mathrm{L}^{-1}$.

Once the treatments were applied, the cuttings were immediately placed in expanded polystyrene (EPS) trays containing 72 cells in an inverted pyramidal shape. Each cell was $120 \mathrm{~cm}^{3}$, which was filled with previously moistened carbonized rice hulls as substrate.

After approximately 90 days, the following variables were assessed: percentage of rooted cuttings; percentage of dead cuttings (with the presence of necrotic tissue); percentage of cuttings with emerged shoots; percentage of cuttings with leaf retention (which kept the initial mature leaf); average length of the three largest roots; and average number of primary roots per cutting.

On each collection date, before and after the rooting period, the total reserve content of the cuttings was determined. The samples were subjected to digestion for the extraction of all reserve substances and products synthesized by the plant, such as carbohydrates, lipids and fatty acids, with only fibers remaining, following an adaptation of the method of Priestley (1965), described below.

In the laboratory, cuttings (without leaves) were packed in paper bags and ovendried at $65^{\circ} \mathrm{C}$ until reaching a constant weight. Subsequently, the material was ground in a mill coupled to a 20-mesh sieve per square inch. One gram of each sample was individually packed in bags made with 'special food filtering mesh', which were tied and ovendried again at $65^{\circ} \mathrm{C}$, until reaching a constant weight. The weight of each bag was recorded (sample). Samples were then placed in a 1-L Erlenmayer flask containing an aqueous solution composed of $5 \%$ trichloroacetic acid (99.0\%) and 35\% methanol (99.8\%), under heating, until the boiling point. As the solution evaporated, distilled water was added so that the samples would be immersed. After $8 \mathrm{~h}$ of boiling, the samples were washed in distilled water and oven-dried again at $65{ }^{\circ} \mathrm{C}$ until reaching a constant weight. The difference between the weight of samples before and after the digestion process represented the reserve content, expressed as in percentage term (\%). For the analysis of the reserve content, 10 samples per collection time were evaluated at the beginning of the experiment; and four samples per block were analyzed at the end, after rooting period.

Results were subjected to analysis of variance. When significant differences were detected by the F test, means were compared by Tukey's test at the $5 \%$ error probability level. Regression analyses were performed for IBA concentrations. Statistical analyses were carried out using Sisvar ${ }^{\circledR}$ software (Ferreira, 2011). 


\section{Results and Discussion}

There was a significant interaction effect between the factors of collection time and IBA concentration for the percentage of rooted cuttings (Figure 2). The cuttings collected in December showed significantly higher percentages, whereas March was the period with the lowest rooting. Rooting was intermediate in the collections carried out in the months of May and August.

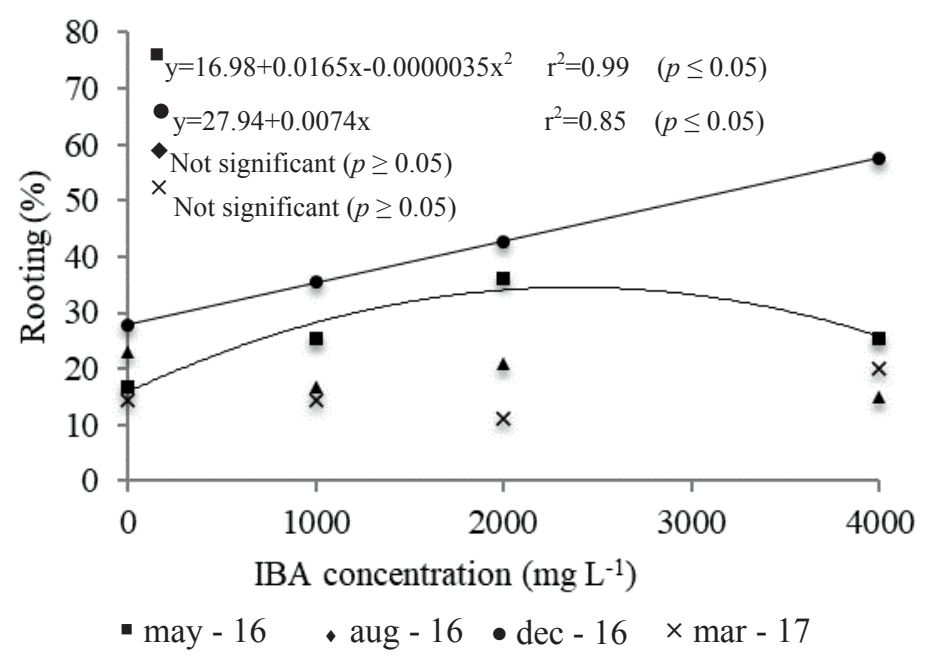

Figure 2. Rooting percentage of 'Bruno' kiwifruit cuttings collected at four times of the year and treated with different concentrations of indolebutyric acid (IBA).

The IBA concentrations only influenced the percentage of rooted cuttings for the collections performed in May and December 2016. In May, this variable showed a positive quadratic response, which was saturated at the calculated concentration of $2,320 \mathrm{mg}$ $\mathrm{L}^{-1}$, with $36.07 \%$ rooting, while in December it responded linearly, reaching $57.59 \%$ of cuttings rooted at the maximum tested concentration. In the collections performed in August 2016 and March 2017, exogenous auxin application did not increase the rooting of the cuttings.

According to Hartmann et al. (2017), in most deciduous species, the response to rooting tends to be greater when they are collected during the dormancy period, in the winter. However, in the present study, this statement was not verified, suggesting the importance of assessing which is the most favorable season for collecting cuttings for each species, to obtain greater rooting. Mattiuz and Fachinello (1996) obtained a similar result in an experiment evaluating different periods of collection of 'Bruno' kiwifruit cuttings in southern Brazil. These authors found that those that were removed in the months of January and April showed greater rooting than the cuttings collected in July, during the dormancy period.

The influence of the time of year on the adventitious root induction process is widely exploited, with very variable results. The period of the year alters the response to rooting 
through changes in exchange activity and the morphophysiological state of the parent plant modifying the levels of growth and nutritional regulators, mainly carbohydrates (Zhang, Fan, Tan, Zhao, \& Cao, 2017).

In the collection carried out in May, some factors may have impaired rooting, in comparison with December. The low temperatures observed in this period, a characteristic condition of southern Brazil, may have inhibited root initiation and development. In addition to the temperature, during this period, deciduous plants such as kiwifruit start to enter dormancy, accumulating a greater amount of phenols and inhibitors, and exhibit low activity of young tissues of the secondary phloem, vascular rays and exchange, resulting in a lesser response to rooting (Hartmann et al., 2017).

In contrast, during the month of August, the plant is already in dormancy, with reduced physiological activity and branches more lignified. According to Passardi, Cosio, Penel and Dunand (2005), a higher degree of lignification may be negatively correlated with auxins, since some enzymes, such as peroxidases, act both on the synthesis of lignin and on the degradation of auxins, a compound that acts by stimulating the emission of adventitious roots.

As for the cuttings collected in December, several factors may have interacted for a better rooting response, such as the consistency of the cutting, balance of plant regulators, content of reserve substances and climatic conditions, especially temperature and humidity.

Anatomically, when the cuttings are removed from the parent plant in periods of intense vegetative growth and with the presence of less lignified tissues, the primary wall of cells is non-thickened, which facilitates root initiation and emergence (Fachinello, Hoffmann, \& Nachtigal, 2005). Likewise, several biochemical processes are altered by temperature, with high temperatures accelerating the speed of reactions and consequently, the metabolism, whereas the low temperatures reduce them (Bergamaschi \& Bergonci, 2017). When cuttings are subjected to environments with high humidity and heat, as in the present study, root emergence is promoted and reaches higher percentages, as cell division and expansion are more intense due to the greater turgidity (Nienow, Chura, Petry, \& Costa, 2010; Souza, Xavier, Leite, Santana, \& Leite, 2013). Figure 1 shows the increase in temperature in the spring and summer months during the study.

In late spring, in the southern region of Brazil, deciduous plants are under intense growth and have vigorous buds. During this period, there is a high activity in meristematic tissues as well as a greater number of young leaves, buds and apical shoots, which are natural sites of production of auxins and cofactors, benefiting the rooting process (Taiz, Zeiger, Møller, \& Murphy, 2017). In fruit trees, this fact was confirmed by Dutra, Kersten and Fachinello (2002), who analyzed the variation of tryptophan levels during the year in peach rootstocks and found that spring and summer were the periods with the lowest concentration of this amino acid, as it had been converted to indoleacetic acid (IAA), the main endogenous auxin present in vegetables.

Also in the December collection, the application of auxins was found to be essential, since its use, at the highest tested concentration, more than doubled the rooting percentage in relation to the treatment without 
IBA (Figure 2). In a study carried out in the northern hemisphere and using herbaceous cuttings of 'Hayward' kiwifruit, Erturk, Ercisli, Haznedar and Cakmakci (2010) obtained better rooting with the rate of $4000 \mathrm{mg} \mathrm{L}^{-1}$, as compared with the IBA concentrations of 0 and $2000 \mathrm{mg} \mathrm{L}^{-1}$.

During the month of March, in turn, the plants had a high number of fruits, and there may have been competition for photoassimilates between branches and fruits. Thus, collecting the cuttings at this time of year resulted in less rooting and also in their death, due to the possible depletion of reserves during the rooting period.

There was an effect of cutting collection period, IBA concentrations and their interaction on the percentage of dead cuttings. The highest mortality was recorded in the collection performed in March, whereas the other collection times did not differ statistically from each other (Table 1).

Table 1

Percentages of dead cuttings (DC), cuttings that produced shoots (PS) and leaf retention (LR), average length of the three largest roots (LLR) and average number of primary roots (NPR) in 'Bruno' kiwifruit cuttings collected at four times of the year and treated with IBA

\begin{tabular}{cccccc} 
Time of the year & DC (\%) & PS (\%) & Analyzed variable \\
& LR (\%) & LLR & NPR \\
\hline May 2016 & $19.29 \mathrm{~b}$ & $0.00 \mathrm{c}$ & $20.84 \mathrm{~b}$ & $3.47 \mathrm{a}$ & $2.05 \mathrm{ab}$ \\
August 2016 & $21.55 \mathrm{~b}$ & $63.52 \mathrm{a}$ & ------ & $3.48 \mathrm{a}$ & $2.22 \mathrm{a}$ \\
December 2016 & $21.86 \mathrm{~b}$ & $44.09 \mathrm{~b}$ & $42.77 \mathrm{a}$ & $4.03 \mathrm{a}$ & $2.27 \mathrm{a}$ \\
March 2017 & $26.66 \mathrm{a}$ & $0.00 \mathrm{c}$ & $35.87 \mathrm{a}$ & $1.92 \mathrm{~b}$ & $1.68 \mathrm{~b}$ \\
C.V (\%) & 35.53 & 23.38 & 42.77 & 42.16 & 30.24
\end{tabular}

Means followed by the same letter in the column do not differ by Tukey's test, at the $5 \%$ error probability level.

The percentage of dead cuttings increased linearly with the increasing IBA concentrations (Figure 3A). This higher mortality may be related to a possible toxicity caused by the absorption of IBA at the highest concentrations. Lattuada, Spier and Souza (2011) found a tendency for leaf fall and a reduction in the survival of pitanga (Eugenia uniflora L.) cuttings with increased quantities of IBA, due to the formation of an abscission layer between the leaf and the cutting caused by auxin.

In terms of shooting, there were significant differences only between the collectiontimes, withnoeffectof theapplication of auxins or an interaction between factors. The cuttings collected in August showed a higher shooting percentage, whereas those removed from the parent plant in the months of March and May did not produce shoots and those collected in December showed intermediate values (Table 1). These findings make it clear how environmental conditions, especially the temperature, have an effect on shoot emergence, where the rise in temperature after the collection period in the dormant cuttings was favorable to the development of the aerial part of the kiwifruit cuttings. 

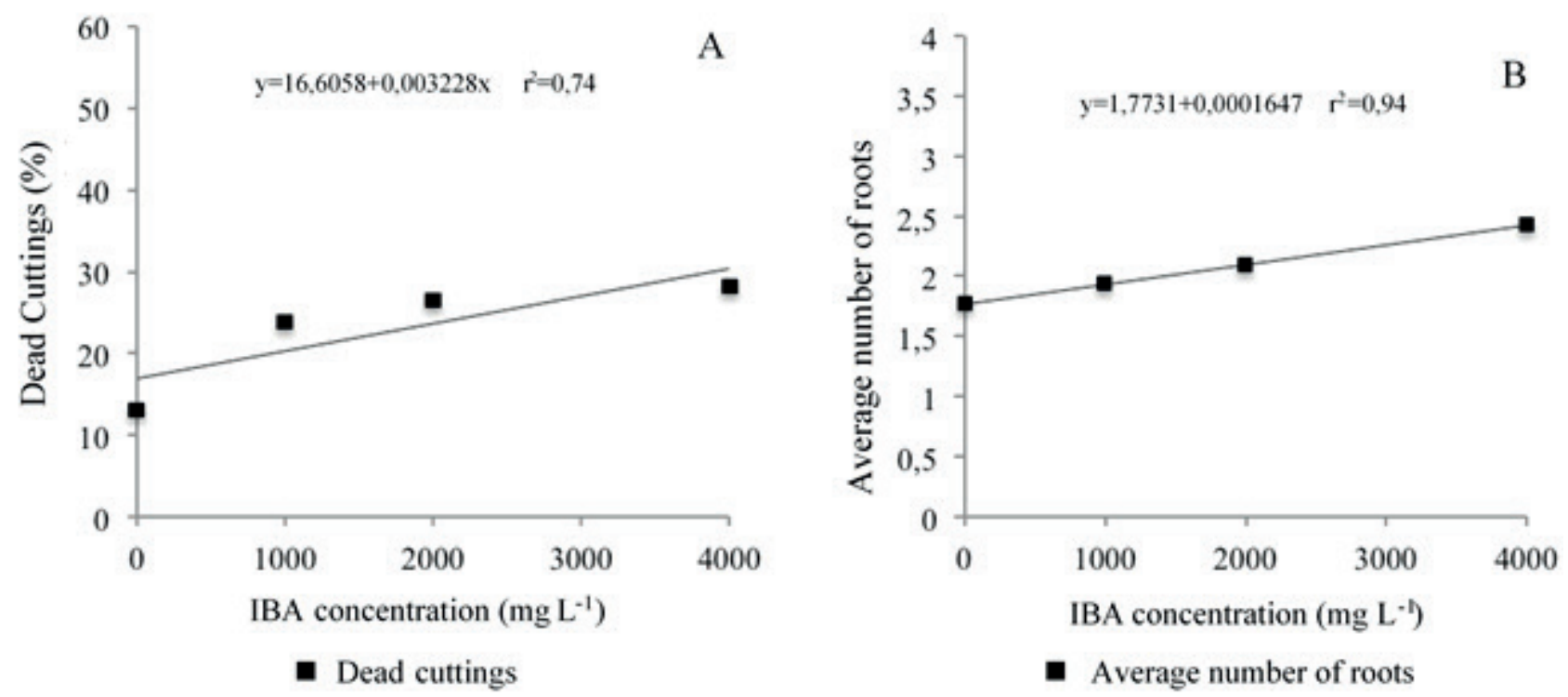

Figure 3. Percentage of dead cuttings $(A)$ and average number of primary roots per cutting (B) in 'Bruno' kiwifruit collected at four times of the year and treated with different concentrations of indolebutyric acid (IBA).

When shoots are produced, the carbohydrates and nitrogen compounds present in the cutting are translocated for the development of the aerial part, which functions as a drain, and these compounds become less available for the formation of the root system. As a result, root emergence is impaired due to the depletion of reserves and death of the cutting. In a study carried out by Pio, Costa, Curi and Moura (2010), woody cuttings of 'Bruno' kiwifruit collected at the end of July showed $100 \%$ shooting, but the rooting percentage was much lower, with $46.7 \%$ of the cuttings rooted.

For the cuttings that maintained the leaves adhered after the rooting period, there was an effect only of the collection period. In this analysis, the collection carried out in winter time was not considered, because the kiwifruit is a deciduous plant. The cuttings collected in the months of December and March showed a higher leaf retention percentage than those collected in May (Table 1). Likewise, in December, there was a greater response to rooting, showing that these factors are positively correlated ( $r=0.61$ in December) and that the presence of leaves on cuttings is important for the rooting of this species.

As stated by Hartmann et al. (2017), leaves on cuttings are sources of auxins and substances that promote rooting. These compounds are translocated to the lower part of the cutting, stimulating rhizogenesis. In addition, the presence of leaves and buds contributes to the formation and initiation of roots through the transport of carbohydrates and other photoassimilates to the base of the cutting. Thus, the early leaf abscission may also have contributed to the lesser rooting of the cuttings collected in May, as compared with those collected in December, since there was possibly not enough time for the transport 
of photoassimilates from the leaves to the base of the cutting.

Only the cutting collection period influenced the average length of the three largest primary roots, with the shortest roots occurring in the cuttings collected in March (Table 1).

The average number of primary roots per cutting was influenced by both the collection period and the auxin concentration, without any interaction between these factors. The lowest amount of roots per cutting (1.68 roots) was observed in the March collection, as shown in Table 1. The average number of primary roots increased linearly in response to tested IBA concentrations, regardless of the period, with the rate of $4000 \mathrm{mg} \mathrm{L}^{-1}$ providing 2.43 roots produced per cutting (Figure $3 \mathrm{~B}$ ).

This reduced number of emerged roots was also described by Pio et al. (2010), who observed two roots per kiwifruit cuttings in both the 'Bruno' and 'Tomuri' cultivars, and 3.3 in 'Alisson'. Root emergence in greater number and length of great importance in the cutting process, as it indirectly constitutes an indication of the quality of the root system. This variable is essential for the formation of an orchard, since a well-formed root system in seedlings increases the area of soil to be explored, favoring the absorption of nutrients and water. In addition, it allows for greater seedling development potential when transplanted into the field (Radmann, Feijo, Goulart, Fischer, \& Bianchi, 2014).

The reserve content in the parent plants at the time of collection differed significantly between the evaluated periods. The largest amount of reserves was observed in the cuttings collected in December (21.10\%), whereas the smallest were found in March and August (14.66\% and $16.09 \%$, respectively). In May, values were intermediate (Table 2).

\section{Table 2}

Relative reserve content of 'Bruno' kiwifruit cuttings collected at four times of the year, before and after the rooting period

\begin{tabular}{ccc} 
Time of the year & \multicolumn{2}{c|}{ Reserve content (\%) } \\
\cline { 2 - 3 } & Before the rooting period & After the rooting period \\
May 2016 & $16.54 \mathrm{~b}$ & $9.11 \mathrm{c}$ \\
August 2016 & $15.09 \mathrm{c}$ & $11.15 \mathrm{~b}$ \\
December 2016 & $21.10 \mathrm{a}$ & $17.10 \mathrm{a}$ \\
March 2017 & $14.66 \mathrm{c}$ & $7.43 \mathrm{~d}$
\end{tabular}

Means followed by the same letter in the column do not differ by Tukey's test, at the $5 \%$ error probability level.

The low rooting percentage obtained in the cuttings collected in March (Figure 2), which averaged $15.23 \%$, may be related to the reduced carbohydrate content of the branches, as a result of the high number of fruits present on the parent plants in this period. Likewise, the highest rooting percentage occurred in December, demonstrating how the carbohydrate content influences root formation in kiwifruit cuttings. 
According to Lebon et al. (2008), the carbohydrates synthesized by photosynthesis are translocated for fruit development and plant respiration as well as for the replacement and storage of reserve tissues. Because fruits consume photoassimilates, a lower number of fruits on the plant results in less drainage force and a consequent positive balance of photoassimilates and greater branch growth, besides accumulation of reserves in the plant structures (Marenco \& Lopes, 2013). Thus, there was a reduction in the reserve content of the branches of the parent plant due to the high fruit load, which impaired rooting. As a management practice, it is recommended to eliminate flowers and fruits from cuttings that will provide parent plants, aiming at greater photoassimilate accumulation and increased rooting potential.

In the materials collected in May and August, there was also a decline in reserve content, which may be related to the mobilization of these branches to permanent plant structures, such as stem and roots. Carbohydrates are also consumed by respiration, since the process of leaf fall begins during this period and the plant thus reduces its photosynthetic activity. These carbohydrates accumulated in the permanent organs act by providing resistance to cold in deciduous plants, as well as by providing energy for the initial shoot growth in the following cycle (Carvalho \& Zanette, 2004).

For this reason, it is recommended to maintain the plant leaves for as long as possible during the fall, aiming at the continuation of the synthesis and replacement of photoassimilates that were removed by the fruits so that there is better plant development and greater production in the spring (Giovannini, 2013). In the present study, results showed it is also important that this accumulation occur for parent plants, as it is related to a higher rooting percentage in cuttings.

After the rooting period, the cuttings that were collected in December maintained the largest reserve content, and those collected in March, the lowest (Table 2). This reinforces how low reserve contents can negatively influence root emergence, which can be explained by the depletion of the carbohydrate content, besides resulting in cutting mortality, as was observed.

There was no significant effect of IBA on the reserve content after the rooting period in any of the periods of the year in which the cuttings were collected.

This study thus demonstrates the importance of the period of collection of propagating material, which, associated with the management of the parent plant, constitute factors that influence the branch reserve content, the plant physiology and, consequently, the rooting of cuttings.

\section{Conclusions}

In the conditions adopted in this experiment, it is recommended to root 'Bruno' kiwifruit cuttings collected in December with the application of $4000 \mathrm{mg} \mathrm{L}^{-1}$ IBA.

\section{Acknowledgments}

The authors thank Capes (Coordination for the Improvement of Higher Education Personnel) for the fellowship grant to the first author; and Embrapa Grape \& Wine for the financial support for the project. 


\section{References}

Bates, T. R., Dunst, R. M., \& Joy, P. (2002). Seasonal dry matter, starch, and nutrient distribution in 'Concord' grapevine roots. Hortscience, 37(2), 313-316. doi: 10.21273/HORTSCI.37.2.313

Bergamaschi, H., \& Bergonci, J. I. (2017). As plantas e o clima: princípios e aplicações. Guaíba, RS: Agrolivros.

Carvalho, R. I. N., \& Zanette, F. (2004). Conteúdo de carboidratos em gemas e ramos de macieira durante o outono e inverno em região de baixa ocorrência de frio. Revista Brasileira de Fruticultura, 26(2), 202-205. doi: 10.1590/S0100-29452004 000200005

Dutra, L. F., Kersten, E., \& Fachinello, J. C. (2002). Época de coleta, ácido indolbutírico e triptofano no enraizamento de estacas de pessegueiro. Scientia Agrícola, 59(2), 327-333. doi: 10.1590/S0103-90162002 000200019

Erturk, Y., Ercisli, S., Haznedar, A., \& Cakmakci, R. (2010). Effects of plant growth promoting rhizobacteria (PGPR) on rooting and root growth of kiwifruit (Actinidia deliciosa) stem cuttings. Biological Research, 43(1), 91-98. doi: 10.4067/S0716-9760201000 0100011

Estatísticas do Comércio Exterior do Agronegócio Brasileiro (2020). Ministério da Agricultura, Pecuária e Abastecimento. Recuperado de http://sistemasweb. agricultura.gov.br/pages/AGROSTAT.

Fachinello, J. C., Hoffmann, A., \& Nachtigal, J. C (2005). Propagação de plantas frutíferas. Brasília, DF: EMBRAPA Informação Tecnológica.
Ferreira, D. F. (2011). Sisvar: a computer statistical analysis system. Ciência e Agrotecnologia, 35(6), 1039-1042. doi: 10.1590/S1413-70542011000600001

Food and Agriculture Organization of the United Nations (2020) Faostat Agricultural production. Recuperado de http://www.fao.org/faostat/en/\#data/QC

Giovannini, E. (2013). Manual de viticultura: série tekne. Porto Alegre, RS: Bookman Editora.

Hartmann, H. T., Kester, D. E., Davies, F. T., Jr., \& Genive, R. L. (2017). Plant propagation: principles and practices. New York, NY: Pearson.

Huang, H. (2016). Kiwifruit: the genus actinidia. Beijing: Academic Press.

Lattuada, D. S., Spier, M., \& Souza, P. V. D. (2011) Pré-tratamento com água e doses de ácido indolburico para estaquia herbácea de pitangueiras. Ciência Rural, 41(12), 2073-2079. doi: 10.1590/S0103-847820 11001200006

Lebon, G., Wojnarowiez, G., Holzapfel, B., Fontaine, F., Vaillant-Gaveau, N., \& Clement, C. (2008). Sugars and owering in the grapevine (Vitis vinifera L.). Journal of Experimental Botany, 59(15), 2565-2578. doi: $10.1093 / j x b / e r n 135$

Marenco, R. A., \& Lopes, N. F. (2013). Fisiologia vegetal:fotossíntese, respiração, relações hídricas e nutrição mineral. Viçosa, MG: Universidade Federal de Viçosa.

Mattiuz, B. H., \& Fachinello, J. C. (1996). Enraizamento de estacas de kiwi Actinidia deliciosa (A. Chev.) C. F. Liang \& A. R. Ferguson var. Deliciosa. Pesquisa Agropecuária Brasileira, 31(7), 503-508. 
Nienow, A. A., Chura, G., Petry, C., \& Costa, C. (2010). Enraizamento de estacas de quaresmeira em duas épocas e concentrações de ácido indolbutírico. Revista Brasileira de Agrociência, 16(14), 139-142. doi: 10.18539/CAST.V16I14.2022

Passardi, F., Cosio, C., Penel, C., \& Dunand, D. (2005). Peroxidases have more functions than a Swiss army knife. Plant Cell Reports, 24(5), 255-265. doi: 10.1007/s00299-005 $-0972-6$

Pimenta, L. V. A. (2018). Estrutura genética da população de Ceratocystis fimbriata associada a kiwi e avaliação da resistência do hospedeiro à Murcha-de-Ceratocystis. Dissertação de mestrado, Universidade Federal de Viçosa, Viçosa, MG, Brasil.

Pio, R., Costa, F. C., Curi, P. N., \& Moura, P. H. M. (2010). Enraizamento de estacas lenhosas de cultivares de kiwizeiro. Scientia Agraria, 11(3), 271-274. doi: 10. 5380/rsa.v11i3.17498

Piveta, G., Alfenas, A. C., Muniz, M. F. B., Valdebenito-Sanhueza, R. M., \& Ferreira M. A. (2013). Ocorrência de Ceratocystis fimbriata em kiwi (Actinidia deliciosa) no sul do Brasil. Revista Brasileira de Fruticultura, 35(2), 665-669. doi: 10.1590/ S0100-29452013000200040

Priestley, G. A. (1965). A new method for the estimation of the resources of apple trees. Journal of the Science of Food and Agriculture, 16(12), 717-721. doi: 10.1002/jsfa.2740161205
Radmann, E. B., Feijo, A. R., Goulart, R. C., Fischer, D. L. O., \& Bianchi, V. J. (2014). Interação entre o genótipo e AIB no enraizamento de estacas semilenhosas de porta-enxertos de pessegueiro. Nativa, 2(4), 229-233. doi: 10.14583/2318-7670. v02n04a08

Silveira, S. V., Anzanello, R., Simonetto, P. R., Gava, R., Garrido, L. R., Santos, R. S. S., \& Girardi, C. L. (2012). Aspectos técnicos da produção de quivi. Bento Gonçalves, RS: EMBRAPA Uva e Vinho.

Smith, J. P., \& Holzapfel, B. P. (2009). Cumulative responses of semillon grapevines to late season perturbation of carbohydrate reserve status. American Journal of Enology and Viticulture, 60(2), 461-470.

Souza, C. C., Xavier A., Leite, F. P., Santana, R. C., \& Leite, H. G. (2013). Padrões de miniestacas e sazonalidade na produção de mudas clonais de Eucalyptus grandis Hill X E. urophylla S. T. Black. Revista Árvore, 37(1), 67-77. doi: 10.1590/S010067622013000100008

Taiz, L., Zeiger, E., Møller, I. M., \& Murphy, A. (2017). Fisiologia e desenvolvimento vegetal. Porto Alegre, RS: Artmed.

Xavier, A., Wendling, I., \& Silva, R. L. (2013). Silvicultura clonal: princípios e técnicas. Viçosa, MG: Editora da UFV.

Zhang, W., Fan, J., Tan, Q., Zhao, M., \& Cao, F. (2017). Mechanisms underlying the regulation of root formation in Malus hupehensis stem cuttings by using exogenous hormones. Journal of Plant Growth Regulation, 36(1), 174-185. doi: 10.1007/s00344-016-9628-8 
